\title{
A fiatalkori növények tápláltsági állapotának értékelése a legelterjedtebb hazai trágyázási szaktanácsadási rendszerek tesztelésére beállított szabadföldi kísérletekben
}

\author{
${ }^{1}$ FODOR NÁNDOR- ${ }^{1}$ CSATHÓ PÉTER-²ÁRENDÁS TAMÁS- \\ ${ }^{1}$ RADIMSZKY LÁSZLÓ-3HORVÁTH JÓZSEF-4NÉMETH TAMÁS \\ ${ }^{1}$ MTA Talajtani és Agrokémiai Kutatóintézet, Budapest \\ ${ }^{2}$ MTA Mezőgazdasági Kutatóintézete, Martonvásár \\ ${ }^{3}$ Talajerógazdálkodás Kkt., Kaposvár \\ ${ }^{4}$ Magyar Tudományos Akadémia
}

\begin{abstract}
Összefoglalás
Az 1960 és 2000 között beállított hazai szabadföldi trágyázási tartamkísérletek adatbázisából származó összefüggésekre alapozva egy új, költség- és környezetkímélő trágyázási szaktanácsadási rendszert hoztunk létre. Az új rendszer célja, hogy a lehetô legkisebb mútrágyahasználat mellett érjünk el nagy terméseket, és a területegységre jutó nettó jövedelem a lehetô legnagyobb legyen.

A Nemzetközi Foszfor Intézet (IMPHOS) anyagi finanszírozásával a különböző hazai trágyázási szaktanácsadási rendszerek tesztelését (az új MTA TAKI - MTA MGKI költség-, és környezetkímélô rendszer, a 'Talajerôgazdálkodás' integrált rendszer és az intenzív MÉM NAK rendszer) egy hároméves program keretében őszi búza, kukorica és tavaszi árpa növényekkel, három jellegzetes talajon (barna erdôtalaj, csernozjom, réti talaj) végeztük el. A kísérletek első öt kezelése egy klasszikus trágyázási hiánykísérletet reprezentált, amelynek célja a trágyázási szaktanácsadási rendszerek talaj NPK ellátottsági határértéke helyes voltának ellenőrzése volt.

Az IMPHOS tesztkísérletek mindhárom talajon, valamennyi növénynél igazolták az MTA TAKI - MTA MGKI költség- és környezetkímélő szaktanácsadási rendszer alapelveinek, mútrágya adag számítási módszerének helyes voltát: Az új MTA TAKI - MTA MGKI rendszer a MÉM NAK intenzív ajánlásával azonos, nagy terméseket eredményezett a MÉM NAK rendszer által javasolt adagok esetenként 40-60\%-ának kijuttatása mellett is.
\end{abstract}


Mindezek eredményeképpen, a területegységre jutó legnagyobb jövedelmeket is az új költség- és környezetkímélő rendszer ajánlásaival kaptuk. A szemtermés eredményekrôl, és a gazdaságossági számításainkról korábbi közleményeinkben számoltunk be. Jelen dolgozatban a diagnosztikai célú növényvizsgálati, talajvizsgálati és NPK mérleg eredményekről számolunk be. Legtöbb esetben, mind a hat szaktanácsadási kezelésben, a búza és tavaszi árpa hajtás, valamint a kukorica levél NPK tartalmak meghaladták a jó ellátottság alsó határát.

A növényi NPK tartalmak a 'Talajerôgazdálkodás' és a 'MÉM NAK' kezelésekben (amelyek nagyobb NPK adagokat javasoltak) legtöbbször nagyobbak voltak, mint az MTA TAKI - MTA MGKI rendszer 4 szintjén kapottak, ugyanakkor a jobb növényi NPK ellátottság a korábbi kezelésekben nem eredményeztek szignifikáns szemtermés többletet.

Figyelembe véve, hogy hasonlóan nagy terméseket sokkal kisebb NPK adagokkal lehetett elérni az MTA TAKI - MTA MGKI rendszer és a Talajerőgazdálkodás rendszer ajánlásaival, mint az intenzív MÉM NAK rendszerével, előbbiek mind agronómiai, mind környezetvédelmi, mind gazdaságossági szempontból kedvezóbbek voltak az utóbbinál.

A kísérletek 3. éve után a PK mérlegértékekben kimutatott különbségek jó összefüggést mutattak a talajok AL-PK tartalmában megnyilvánuló eltérésekkel.

Kulcsszavak: trágyázási szaktanácsadási rendszer, tesztkísérlet, ôszi búza, kukorica, tavaszi árpa, diagnosztikai növényvizsgálat, AL-PK tartalom, NPK mérleg

\title{
Evaluation of the nourishment conditions of young crops in the field experiment established to test the most widespread Hungarian fertilisation recommendation systems
}

\author{
${ }^{1}$ N. FODOR- ${ }^{1}$ P. CSATHÓ- ${ }^{2}$ T. ÁRENDÁS- ${ }^{1}$ L. RADIMSZKY- \\ ${ }^{3}$ J. HORVÁTH- ${ }^{4}$ T. NÉMETH
}

${ }^{1}$ Research Institute for Soil Science and Agricultural Chemistry of the Hungarian Academy of Sciences, Budapest

${ }^{2}$ Agricultural Research Institute of the Hungarian Academy of Sciences, Martonvásár

${ }^{3}$ Talajerőgazdálkodás Kkt., Kaposvár

${ }^{4}$ Hungarian Academy of Sciences 


\section{Summary}

Based on correlations calculated from the database of long-term fertilisation experiments carried out in Hungary between 1960 and 2000, a new, cost-saving and environmental friendly fertiliser recommendation system was developed. The aim of the new system is to apply the lowest possible NPK rates required to achieve high yields and the maximum income per unit area.

The World Phosphorus Institute (IMPHOS) agreed to finance a three-year programme for the testing of various Hungarian fertiliser recommendation systems (the new 'RISSAC - RIA' system, the 'Talajerôgazdálkodás' integrated soil fertility management system, and the intensive 'MÉM NAK' system) when applied to three major crops grown on three characteristic Hungarian soils. The first five treatments in the experiment represented a classical deficiency experiment, aimed at checking the correctness of the NPK-supply categories determined by the various systems.

On all three soils and for all three crops, the IMPHOS experiments confirmed the basic principles of the new cost-saving, environment-friendly fertiliser recommendation system, and the correctness of the methods used for calculating fertiliser rates. In this paper, diagnostic plant analysis, as well as soil analysis data, and NPK balances, obtained in the different recommendations are discussed. In most cases the plant NPK contents of all the recommendations exceeded the lower limits of the good NPK supply category for wheat and barley shoot as well as for corn leaf.

Crop NPK contents in 'Talajerógazdálkodás' and 'MÉM NAK' treatments (with higher recommended NPK doses) were mostly higher than in the 'RISSAC-RIA' treatments, however, the better crop NPK status did not result in extra grain yield in the former treatments.

Taking into account, that similarly high yields were obtained by using the 'RISSAC - RIA' system and the 'Talajerôgazdálkodás' integrated system with much smaller NPK doses than that were recommended by the intensive MÉM NAK system, they were more advantageous both from agronomic and environmental protection as well as from economic point of view.

Differences in PK balances were in good correlation with the differences in the measured soil AL-PK contents after the third year of the experiment.

Key words: fertiliser recommendation system, test experiment, wheat, corn, barley, diagnostic plant analysis, soil PK test, NPK balance 


\section{Bevezetés}

A talaj „könnyen oldható” tápelem tartalma, ill. a diagnosztikai célú növényvizsgálati adatok csak tenyészedény- és szabadföldi trágyázási kísérletekben való kalibrálásuk után használhatók trágyázási szaktanácsadási rendszerekben (Jones 1967, Khasawneh et al. 1980, Munson 1985, Bergmann 1992, Peverill et al. 1999, Reuter et al. 1997, Izsáki 2006, 2007, 2008, 2009, Izsáki és Németh 2007).

Az 1960 és 2000 között beállított hazai szabadföldi NPK trágyázási tartamkísérletek adatbázisából származó összefüggésekre alapozva (Csathó 2003abcde, 2004ab, 2005ab, Németh 2006), az MTA Talajtani és Agrokémiai Kutatóintézet, Budapest, és az MTA Mezőgazdasági Kutatóintézete, Martonvásár szakemberei egy új, költség- és környezetkímélő trágyázási szaktanácsadási rendszert dolgoztak ki (Csathó et al. 1998). Az új rendszer négy trágyázási szinten ad szaktanácsokat: 1) minimum; 2) környezetkíméloo; 3) mérleg-szemléletú; 4) maximum szint.

A trágyázási szaktanácsadási rendszereket - az újonnan nemesített növényfajtákhoz, hibridekhez hasonlóan - szabadföldi kísérletekben szükséges tesztelni (Olson et al. 1982, Csathó et al. 2007) .

A kukorica és a búza, mint két legfontosabb termesztett növényünk, valamint a tavaszi árpa, mely mind takarmány- mind söripari célokra is használható, kerültek kiválasztásra, mint tesztnövények. A korábbi magyarországi szabadföldi mútrágyázási tartamkísérletek tanúsága szerint az ôszi búza és a tavaszi árpa $\mathrm{N}$ - és $\mathrm{P}$ - igényes, míg a kukorica $\mathrm{N}$ - és $\mathrm{K}$ - igényes növény (Kadlicskó és Krisztián 1977, Győrffy 1979, Kismányoky et al. 1989, Holló et al. 1991, Lásztity 1991, Kádár 1992, 1994, Debreczeni és Debreczeni 1994, Debreczeni és Németh 2009).

Hároméves, három jellegzetes magyarországi talajon beállított szabadföldi kísérletben teszteltük a különbözó hazai trágyázási szaktanácsadási rendszerek ajánlásait mind agronómiai, mind gazdaságossági szempontból (Csathó et al. 2007). A fiatalkori növények tápláltsági állapotáról ebben a közleményben számolunk be. Értékeljük a kísérlet harmadik éve után a talajok könnyen oldható PK tartalmában, és NPK mérleg értékeiben beállt változásokat is. 


\section{Anyag és módszer}

2003 ôszén, a Nemzetközi Foszfor Intézet (IMPHOS) finanszírozásában hároméves, szabadföldi trágyázási kísérletek kerültek beállításra véletlen blokk elrendezésben, három ismétlésben (bruttó parcella: 74-80 $\mathrm{m}^{2}$ ) a legfontosabb hazai trágyázási szaktanácsadási rendszerek ajánlásainak tesztelésére: az új MTA TAKI - MTA MGKI költség- és környezetkímélố rendszer négy szintje, a Talajerôgazdálkodás integrált (www.talajerogazdalkodas.hu), valamint a MÉM NAK (1979) intenzív szaktanácsadási rendszer ajánlásait.

Az elsố évben, 2003/2004-ben ôszi búza szerepelt mind a három kísérletben, amelyet 2005-ben kukorica, majd 2006-ban tavaszi árpa követett.

Az elsố három évben a kísérletekben kapott szemtermés mennyiségekrôl, és a gazdaságossági számításainkról korábbi közleményeinkben számoltunk be (Csathó et al. 2007, 2009, Sulyok et al. 2007ab). A gazdaságossági számítások során az egyes ajánlási szinteken eltérô adagokban kijuttatott mútrágyák árán kívül valamennyi költséget azonosnak tekintettünk. A termelési költségeket az adott évi árviszonyok alapján vettük számításba. Értelemszerúen, az egyes ajánlási szinteken kapott eltérô termésmennyiségekből származó bevételek is különbözőek voltak. A fốtermés egységnyi árának megszabásakor a tôzzdei terményárak szolgáltak iránymutatóul. A leggazdaságosabbnak azt a kezelést tekintettük, ahol a termésekbő́l származó árbevétel és az adott termés eléréséhez szükséges mútrágya ára közötti különbség, azaz a területegységre jutó jövedelem a legnagyobb volt. Jelen cikkben a „leggazdaságosabb kezelés” fogalmat ilyen értelemben használjuk.

Az ôszi búza és a tavaszi árpa hajtásokat a bokrosodás végén - szárbaindulás elején (Feekes 5-6) (4-4 folyóméterrôl) a kukorica csôvel szembeni levélmintákat (20-20 levél) virágzáskor, a talajmintákat a $0-20 \mathrm{~cm}$ rétegből, 20-20 pontminta egyesítésével, a harmadik évben betakarítás után vettük meg.

A növények összes NPK tartalmát cc. $\mathrm{HNO}_{3}+30 \% \mathrm{H}_{2} \mathrm{O}_{2}$ roncsolás után határoztuk meg.

A növényi NPK ellátottság alsó határait az alábbi koncentráció értékekkel vettük figyelembe:

N: ôszi búza hajtás: 3\% (Bergmann 1992), kukorica levél: 2,7\% (Jones et al. 1991), tavaszi árpa hajtás: 2,8\% (Bergmann 1992),

P: ôszi búza hajtás: 0,3\%, (Bergmann 1992), kukorica levél: 0,25\% (Jones 1967), tavaszi árpa hajtás: 0,35\% (Bergmann 1992), 
K: ôszi búza hajtás: 3,5\% (Bergmann 1992), kukorica levél: 1,7\% (Jones 1967), tavaszi árpa hajtás: 3\% (Bergmann 1992).

A talaj könnyen oldható PK tartalmát az AL- módszerrel határoztuk meg (Egner et al. 1960).

A talaj PK ellátottságának értékelésekor a hazai szabadföldi trágyázási tartamkísérletek adatbázisából származó összefüggések alapján megállapított új AL-PK határértékeket vettük figyelembe (Csathó 2002, 2005ab). A CaCO 3 tartalmakat Scheibler féle kalciméterrel (Buzás 1988), a pH értékeket a KCl-es módszerrel (Buzás 1988), a talaj szervesanyag tartalmát Tyurin (1937) módszerével határoztuk meg.

A 3 IMPHOS kísérletben a talajtulajdonságok az alábbiak voltak:

A. IMPHOS 1 kísérlet, Balatonszentgyörgy. Ramann féle barna erdôtalaj. Talajtulajdonságok: fizikai féleség: homokos vályog; $\mathrm{pH}_{\mathrm{KCl}}$ : 6,45; $\mathrm{CaCO}_{3}$ tartalom: -; humusztartalom: 1,62\%; N-ellátottság: gyenge; $\mathrm{AL}-\mathrm{P}_{2} \mathrm{O}_{5}: 98 \mathrm{mg} / \mathrm{kg}$; P-ellátottság: közepes a búza és a tavaszi árpa, jó a kukorica számára; AL$\mathrm{K}_{2} \mathrm{O}: 198$ mg/kg; K-ellátottság: jó a búza és a tavaszi árpa, közepes a kukorica számára.

B. IMPHOS 2 kísérlet, Mezôkövesd. Réti talaj. Talajtulajdonságok: fizikai féleség: agyagos vályog; $\mathrm{pH}_{\mathrm{KCl}}$ : 4,49; $\mathrm{CaCO}_{3}$ tartalom: -; humusztartalom: 3,43\%; N-ellátottság: jó; AL- $\mathrm{P}_{2} \mathrm{O}_{5}: 38 \mathrm{mg} / \mathrm{kg}$; P-ellátottság: gyenge a búza és a tavaszi árpa, közepes a kukorica számára; AL-K 2 O: 209 mg/kg; K-ellátottság: igen jó búza és a tavaszi árpa, jó a kukorica számára. Meszet 2 t/ha adagban az ôszi búza vetése elôtt juttattunk ki.

C. IMPHOS 3 kísérlet, Nagyhörcsök. Mészlepedékes csernozjom talaj. Talajtulajdonságok: fizikai féleség: vályog; $\mathrm{pH}_{\mathrm{KCl}}$ : 7,1; $\mathrm{CaCO}_{3}$ tartalom: 3,9\%; humusztartalom: 2,95\%; N-ellátottság: közepes; $\mathrm{AL}-\mathrm{P}_{2} \mathrm{O}_{5}: 78 \mathrm{mg} / \mathrm{kg}$; $\mathrm{P}$ ellátottság: gyenge a búza és a tavaszi árpa, közepes a kukorica számára; AL$\mathrm{K}_{2} \mathrm{O}: 152 \mathrm{mg} / \mathrm{kg}$; K-ellátottság: jó a búza és a tavaszi árpa, közepes a kukorica számára. 


\section{Kísérleti eredmények és érékelésük}

\section{A diagnosztikai célú növényvizsgálati eredmények értékelése}

\section{IMPHOS öszi búza kísérletek, 2004}

2003/2004-ben az időjárás kedvező volt az ôszi búzára, ami a nagyobb átlagtermésekben is megmutatkozott. A különböző szaktanácsadási rendszerek által javasolt NPK adagokról és a búza bokrosodás végi hajtás légszáraz tömegérôl az 1. táblázatból tájékozódhatunk. Az ôszi búza mútrágyahatásokról a szemtermések mennyiségére elôzô közleményünkben adtunk számot (Csathó et al. 2007). A kísérlet elsô hat kezelése egy klasszikus hiánykísérletet reprezentált, melynek célja a különböző trágyázási szaktanácsadási rendszerek talaj NPK ellátottsági határértékeinek ellenôrzése, helyességük megállapítása volt. Az utolsó hat kezelés a legfontosabb hazai trágyázási szaktanácsadási rendszerek ajánlásait jelentette: az új, költség- és környezetkímélő MTA TAKI - MTA MGKI szaktanácsadási rendszer négy szinten ad ajánlásokat: 1) minimum;2) környezetkímélő; 3) mérleg-szemléletű; 4) maximum növénytáplálási szint; a Talajerôgazdálkodás integrált rendszer jelentette az ötödik, a MÉM NAK intenzív rendszer a hatodik szaktanácsadási kezelést (1. táblázat).

A bokrosodás végén - szárbaindulás elején (Feekes 5-6) vett ôszi búza hajtás diagnosztikai célú növényvizsgálati eredményekrôl az 1. táblázatból és az 1. ábrából tájékozódhatunk. A három kísérleti hely közül, a búza hajtás NPK tartalmak a balatonszentgyörgyi (IMPHOS 1) kísérletekben voltak a legnagyobbak. A hajtás NPK tartalmakban megjelenő NPK hatások is itt voltak a legkifejezettebbek. A búza hajtás N\%-okban kapott N hatások az IMPHOS 1 kísérletben (gyenge N ellátottság), és az IMPHOS 3 kísérletben (közepes $\mathrm{N}$ ellátottság) nagyobbak voltak, mint az IMPHOS 2 kísérletben (jó N ellátottság). A bokrosodás végi búza hajtás jó ellátottságának alsó határát figyelembe véve (N: 3\%; P: 0,3\%; K: 3,5\%, Bergmann 1992), a növényi NPK koncentrációk a hat mútrágyázási szaktanácsadási kezelésben meghaladták ezeket a határértékeket, jelezve az ôszi búza kielégítő NPK ellátottságát. Egyedüli kivételt a nagyhörcsöki (IMPHOS 3) kísérlet jelentett, ahol a búza K tartalmak valamivel a jó K ellátottság alsó határa alatt maradtak. Ugyanakkor, az ôszi búza szemtermés eredményeket figyelembe véve, ebben a kísérletben, káliumhiány okozta szignifikáns terméscsökkenést sem tapasztaltunk (Csathó et al. 2007). 


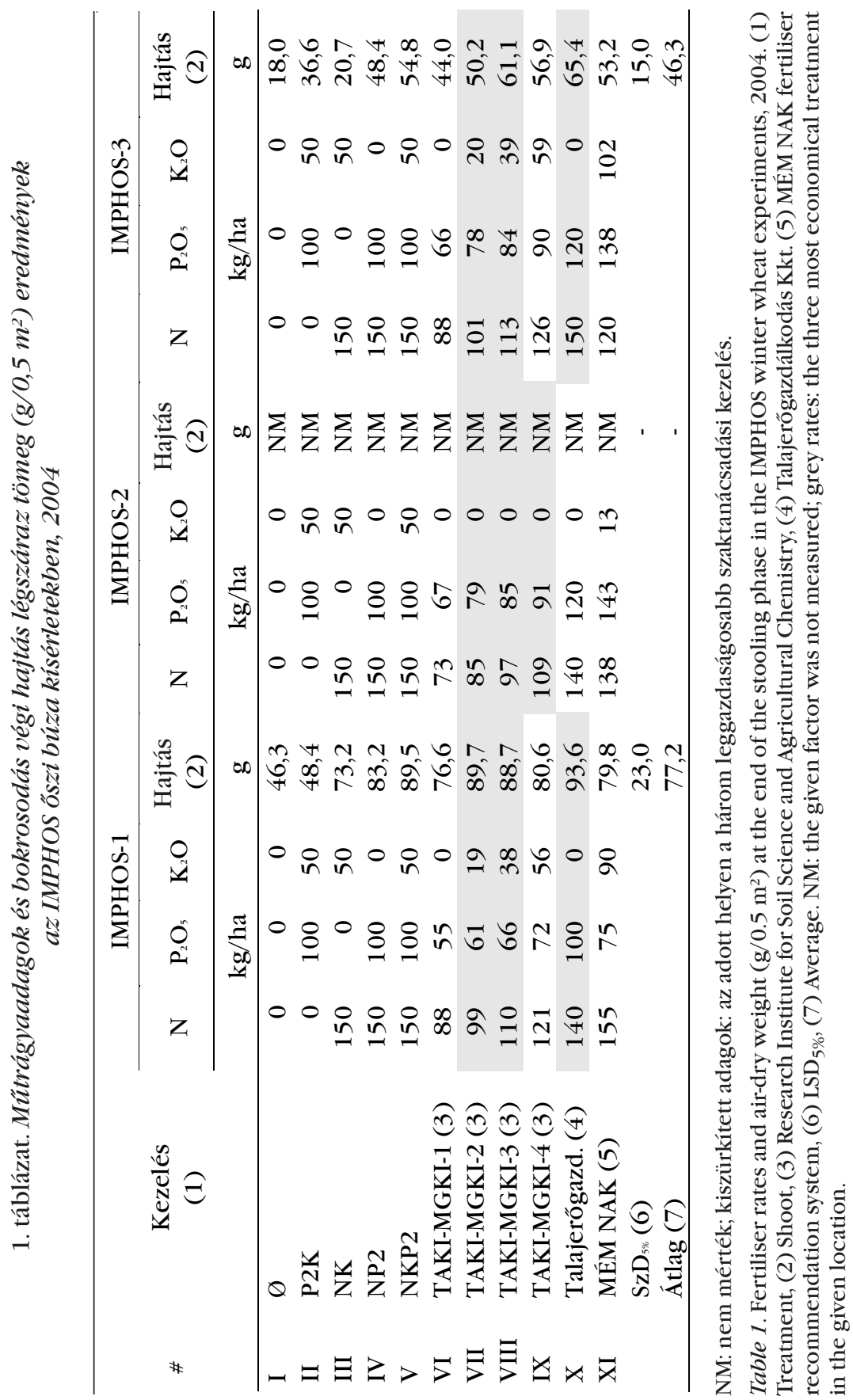


1. ábra. Az ôszi búza bokrosodás végi (Feekes 5-6) hajtás NPK tartalmai az IMPHOS kisérletekben, 2004

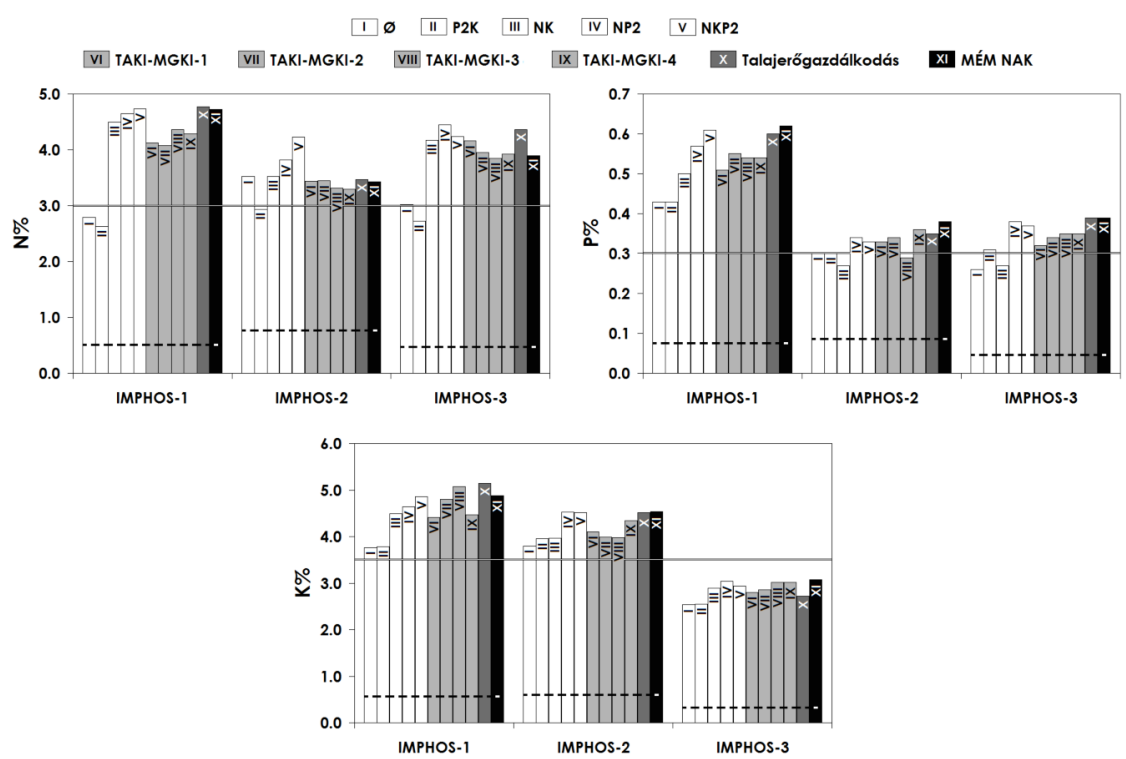

A folytonos vízszintes vonalak a jó ellátottság alsó határát, míg a szaggatott vonalak az $\mathrm{SzD}_{5 \%}$ értékeket jelzik.

Figure 1. NPK contents of the winter wheat shoot at the end of the stooling phase (Feekes 5-6) in the IMPHOS experiments, 2004. Continuous horizontal lines represent the lower margin of good level of supply, whereas dashed lines show $\mathrm{LSD}_{5 \%}$ values.

Az ôszi búza hajtás NPK tartalmak a Talajerôgazdálkodás és a MÉM NAK ajánlásokban (ahol az NPK adagok is nagyobbak voltak) általában magasabbak voltak az MTA TAKI - MTA MGKI rendszer ajánlásainál kapottaknál, ugyanakkor a jobb növényi NPK státus nem jelentkezett többlet szemtermés mennyiségekben (1. táblázat, 1. ábra, Csathó et al. 2007).

\section{IMPHOS kukorica kisérletek, 2005}

2005-ben az idôjárás különösen kedvezố feltételeket teremtett a nagy kukorica termések eléréséhez. Télen és tavasszal átlagos mennyiségú csapadék hullott, a nyár ugyanakkor meleg és igen csapadékos volt, júliusban és augusztus a sokévi átlag 2-3-szorosa hullott. Ezek a kedvezó körülmények mind a három kísérleti helyen $10 \mathrm{t} / \mathrm{ha}$ feletti terméseket eredményeztek.

A kísérletekben kapott szemtermés eredményeket korábbi közleményünkben is ismertettük (2. táblázat) (Csathó et al. 2007). 


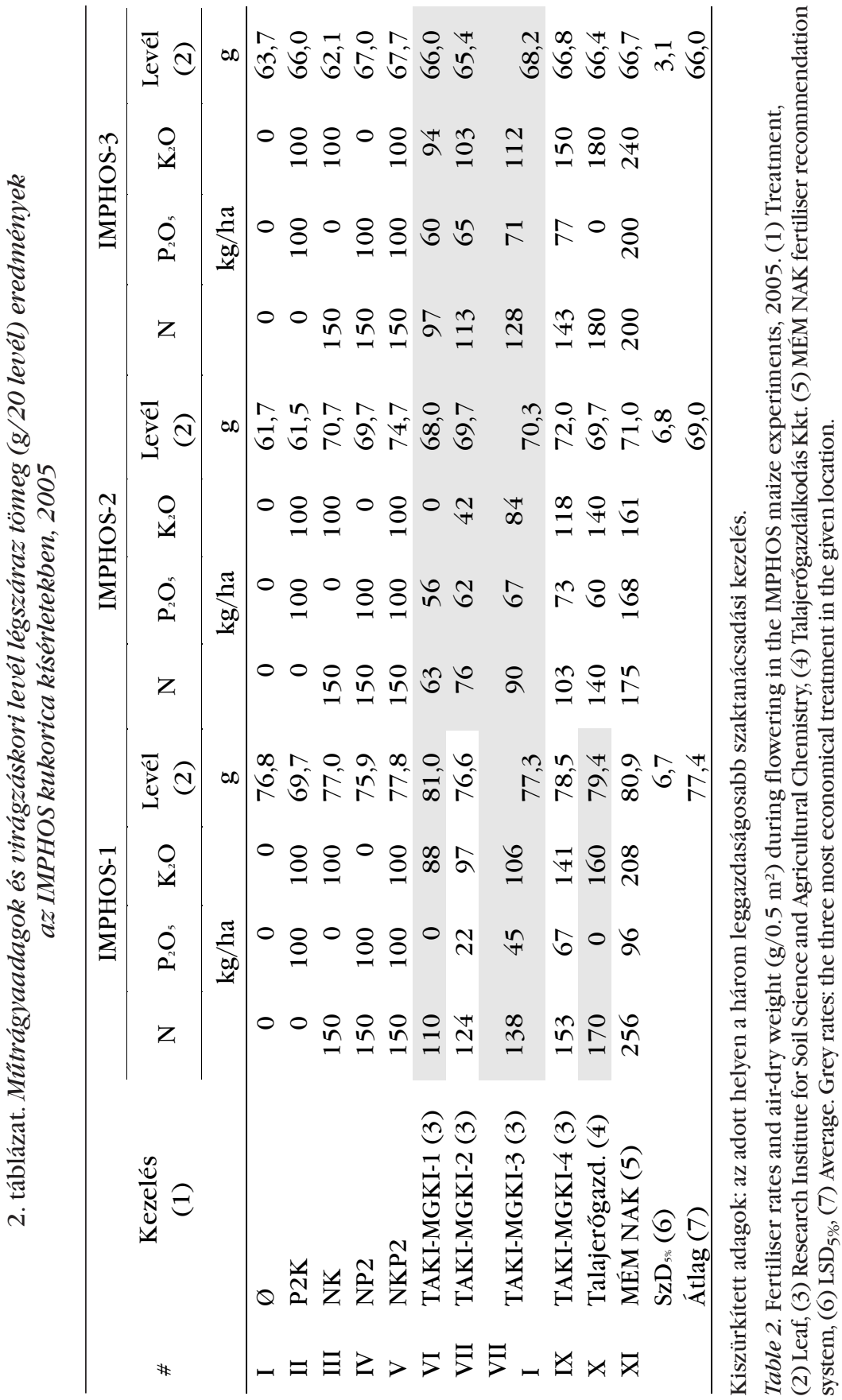


A kukorica virágzáskori, csővel szemközti levél diagnosztikai célú vizsgálati adatait a 2. ábrán és a 2. táblázatban tanulmányozhatjuk. A három kísérleti hely között a kukorica levél NPK tartalmakban megnyilvánuló különbségek sokkal kisebbek voltak, mint az ószi búza hajtás NPK tartalmakban tapasztaltak. A három kísérleti hely közül ismét csak az IMPHOS 1 kísérlet kukorica levél, különösen a $\mathrm{K}$ tartalmai voltak valamivel nagyobbak, mint a másik két helyen. A kukorica levél N\%-okban kapott $\mathrm{N}$ hatások az IMPHOS 1 kísérletben (gyenge N ellátottság), és az IMPHOS 3 kísérletben (közepes N ellátottság) nagyobbak voltak, mint az IMPHOS 2 kísérletben (jó N ellátottság). A virágzáskori kukorica levél jó ellátottságának alsó határát figyelembe véve (N: 2,7\%; P: 0,25\%; K: 1,7\%,Jones et al. 1991; Jones 1967), a növényi NPK koncentrációk a hat mútrágyázási szaktanácsadási kezelésben ismét meghaladták ezeket a határértékeket, jelezve a kukorica jó NPK ellátottságát.

\section{2. ábra. A kukorica virágzáskori, csóvel szemközti levél NPK tartalmai} az IMPHOS kísérletekben, 2005

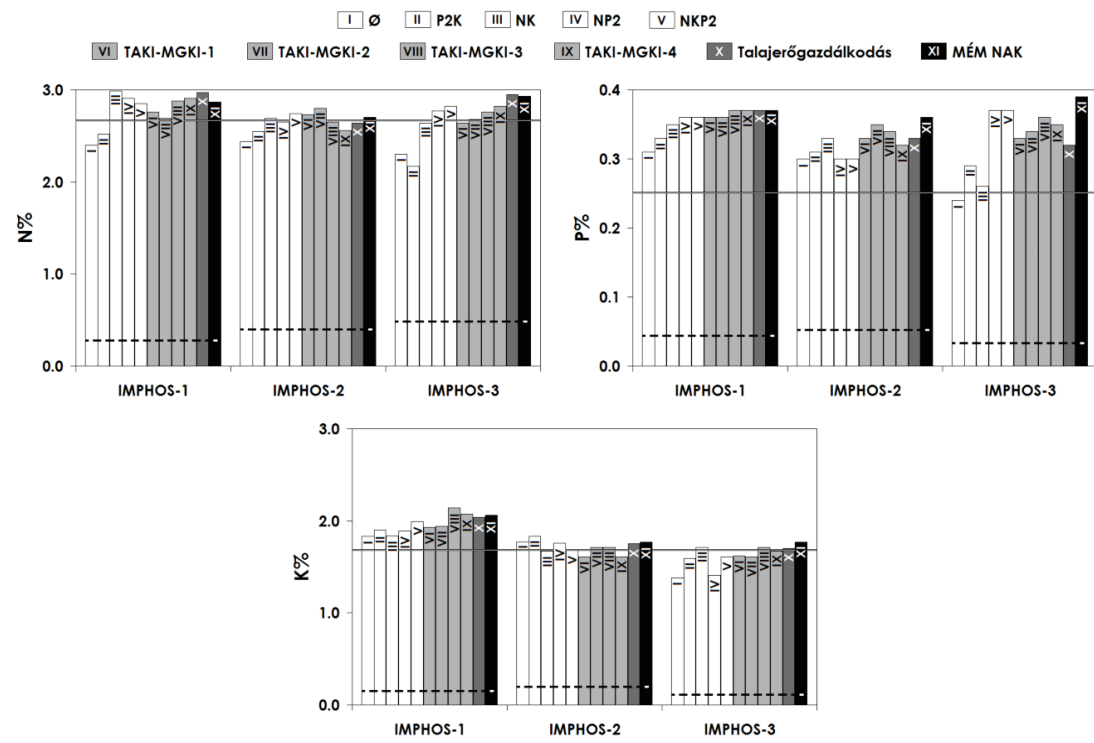

A folytonos vízszintes vonalak a jó ellátottság alsó határát, míg a szaggatott vonalak az $\mathrm{SzD}_{5 \%}$ értékeket jelzik.

Figure 2. The NPK contents of the maize leaf on the opposite side of the ear during flowering in the IMPHOS experiments, 2005. Continuous horizontal lines represent the lower margin of good level of supply, whereas dashed lines show $\mathrm{LSD}_{5 \%}$ values. 
A kukorica levél NPK tartalmak a Talajerôgazdálkodás és a MÉM NAK ajánlásokban (ahol az NPK adagok is nagyobbak voltak) többször is magasabbak voltak az MTA TAKI - MTA MGKI rendszer ajánlásainál kapottaknál, ugyanakkor a nagyobb növényi NPK tartalmak nem jelentkeztek többlet szemtermés mennyiségekben (2. táblázat, 2. ábra, Csathó et al. 2007).

\section{IMPHOS tavaszi árpa kísérletek, 2006}

Az időjárás a korábbi két évhez hasonlóan 2006-ban is kedvező volt az IMPHOS kísérletek számára, viszonylag nagy tavaszi árpa szemtermés eredményeket eredményezve. Ugyanakkor a csapadékos tavasz miatt a mezőkövesdi agyagos vályog fizikai féleségú talajon (IMPHOS 2 kísérlet) időszakos vízállások alakultak ki, amelyek foltszerúen károsították az állományt.

A kísérletekben kapott tavaszi árpa szemtermés mennyiségekról korábbi közleményünkben számoltunk be (Csathó et al. 2007).

A tavaszi árpa $\mathrm{N}$ adagokat sörárpa hasznosításra állapítottuk meg (3. táblá$z a t)$.

A bokrosodásvégén-szárbaindulás elején (Feekes 5-6) vett tavaszi árpa hajtás diagnosztikai célú növényvizsgálati eredményeirôl a 3. ábrában számolunk be.

A három kísérleti hely közül az árpa hajtás N és K tartalmak a nagyhörcsöki (IMPHOS 3), míg a P koncentrációk a balatonszentgyörgyi (IMPHOS 1) kísérletben voltak a legnagyobbak. Az árpa hajtás NPK tartalmakban kifejezett NPK hatások is az utóbbi kísérletben voltak a legnagyobbak. Az árpa hajtás N\%-okban kapott N hatások, a másik két növényhez hasonlóan, az IMPHOS 1 kísérletben (gyenge N ellátottság), és az IMPHOS 3 kísérletben (közepes N ellátottság) nagyobbak voltak, mint az IMPHOS 2 kísérletben (jó N ellátottság). A bokrosodás végi tavaszi árpa hajtás jó ellátottságának alsó határát figyelembe véve (N: 2,8\%; P: 0,35\%; K: 3,0\%, Bergmann 1992), a növényi NPK koncentrációk a hat mútrágyázási szaktanácsadási kezelésben meghaladták ezeket a határértékeket, jelezve a kielégítő NPK ellátottságokat. Az egyedüli kivételt a mezőkövesdi (IMPHOS 2) kísérlet képviselte, ahol az árpa hajtás N tartalmak a jó N ellátottság alsó határa alatt maradtak. A balatonszentgyörgyi (IMPHOS 1) kísérletben szintén a jó ellátottság alsó határa alatt maradtak a hajtás $\mathrm{N}$ tartalmak. Ugyanakkor, a tavaszi árpa szemtermés eredményeket figyelembe véve, ezekben a kísérletekben, $\mathrm{N}$ hiány okozta szignifikáns terméscsökkenést sem tapasztaltunk (Csathó et al. 2007). 


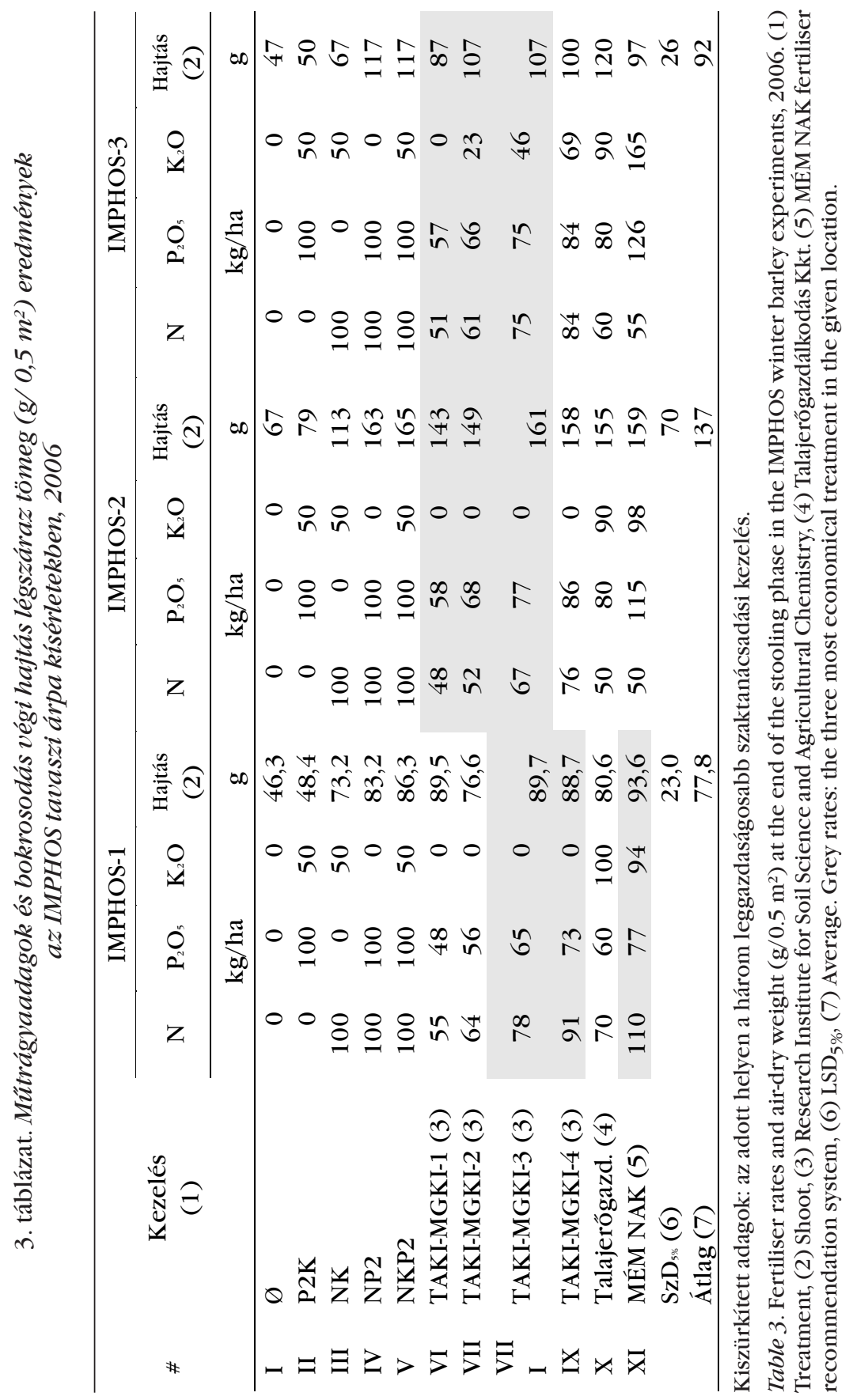


3. ábra. A tavaszi árpa bokrosodás végi (Feekes 5-6) hajtás NPK tartalmai az IMPHOS kisérletekben, 2006

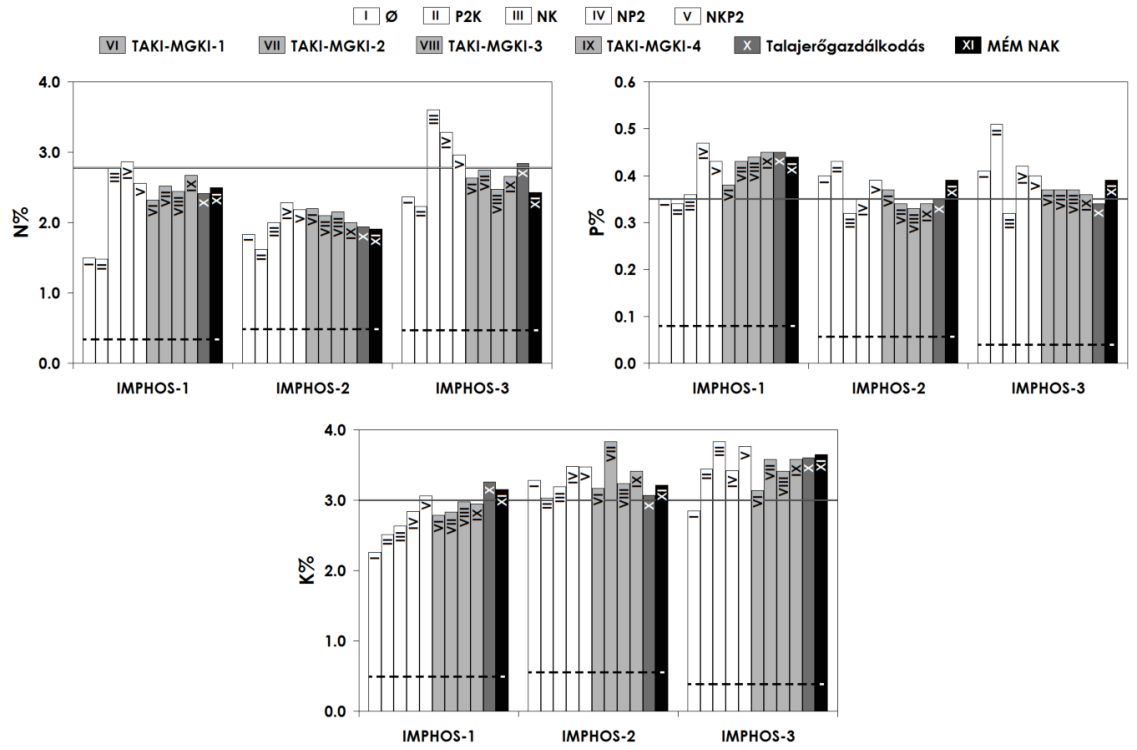

A folytonos vízszintes vonalak a jó ellátottság alsó határát, míg a szaggatott vonalak az $\mathrm{SzD}_{5 \%}$ értékeket jelzik.

Figure 3. NPK contents of the winter barley shoot at the end of the stooling phase (Feekes 5-6) in the IMPHOS experiments, 2006. Continuous horizontal lines represent the lower margin of good level of supply, whereas dashed lines show $\mathrm{LSD}_{5 \%}$ values.

Mint ismeretes, a sörárpa minôségi mutatóit a túlzott N kínálat jelentôsen ronthatja (3. táblázat, 3. ábra).

A tavaszi árpa hajtás NPK tartalmak a Talajerôgazdálkodás és a MÉM NAK ajánlásokban (ahol az NPK adagok is nagyobbak voltak) többször is magasabbak voltak az MTA TAKI - MTA MGKI rendszer ajánlásainál kapottaknál, ugyanakkor a nagyobb növényi NPK tartalmak nem jelentkeztek többlet szemtermés mennyiségekben (3. táblázat, 3. ábra, Csathó et al. 2007).

\section{A talaj tápelem vizsgálati eredmények értékelése}

A harmadik évi tavaszi árpa betakarítás után a talaj könnyen oldható (Egner et al. 1960) AL, PK tartalma meghatározása céljából talajmintákat vettünk (4. AB. ábra). 
4. ábra. A talaj AL-PK tartalmai az IMPHOS kísérletek harmadik éve után, 2006 öszén

A: $\mathrm{AL}-\mathrm{P}_{2} \mathrm{O}_{5}$ tartalmak

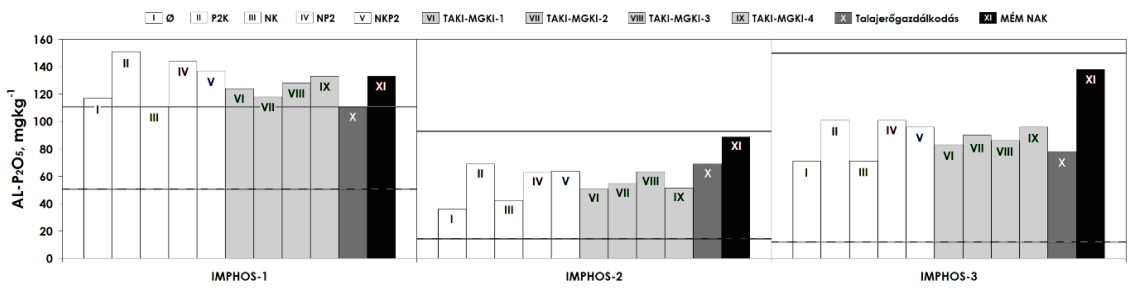

B: AL- $\mathrm{K}_{2} \mathrm{O}$ tartalmak

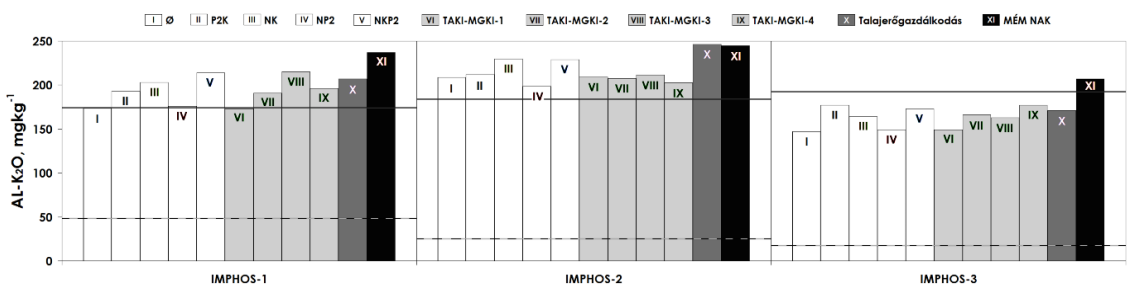

A folytonos vízszintes vonalak a jó ellátottság alsó határát, míg a szaggatott vonalak az $\mathrm{SzD}_{5 \%}$ értékeket jelzik.

Figure 4. AL-PK contents of the in autumn 2006, after the third year of the IMPHOS experiments. A: AL- $\mathrm{P}_{2} \mathrm{O}_{5}$ contents; $\mathrm{B}$ : AL- $\mathrm{K}_{2} \mathrm{O}$ contents. Continuous horizontal lines represent the lower margin of good level of supply, whereas dashed lines show $\mathrm{LSD}_{5 \%}$ values.

A három kísérleti helyet összehasonlítva, a talaj $\mathrm{AL}-\mathrm{P}_{2} \mathrm{O}_{5}$ tartalmak a kísérlet harmadik éve után összefüggést mutattak a kísérletek beállításakor, 2003 ószén mért AL- $\mathrm{P}_{2} \mathrm{O}_{5}$ tartalmakkal, amelyek közepes-jó P ellátottságot jeleztek az IMPHOS 1 kísérletben, és gyenge P ellátottságot az IMPHOS 2 és IMPHOS 3 kísérletekben.

A harmadik év után, a balatonszentgyörgyi (IMPHOS 1) kísérlet mind a hat szaktanácsadási kezelésében jó $\mathrm{P}$ ellátottságokat állapítottunk meg (jó $\mathrm{P}$ ellátottság alsó határa: $111 \mathrm{mg} / \mathrm{kg}$ AL- $\mathrm{P}_{2} \mathrm{O}_{5}$, Csathó 2002). Ugyanakkor a P ellátottság gyenge maradt a mezókövesdi (IMPHOS 2) (jó P ellátottság alsó határa: $93 \mathrm{mg} / \mathrm{kg} \mathrm{AL}-\mathrm{P}_{2} \mathrm{O}_{5}$, Csathó 2002) és a nagyhörcsöki (IMPHOS 3) (jó P ellátottság alsó határa: $150 \mathrm{mg} / \mathrm{kg} \mathrm{AL}-\mathrm{P}_{2} \mathrm{O}_{5}$, Csathó 2002) kísérletekben (4. A. ábra).

Ez alól csupán a MÉM NAK intenzív rendszer kezelése volt kivétel, amely jó ellátottságot mutatott az IMPHOS 2 kísérletben, és a közepes P ellátottság felsó 
részén helyezkedett el az IMPHOS 3 kísérletben. Mint ahogy a költség- és környezetkímélő MTA TAKI - MTA MGKI rendszer és az intenzív MÉM NAK rendszer filozófiájának összehasonlításkor jeleztük is, az előbbi „a növény trágyázásával”, míg az utóbbi „a talaj trágyázásával” jellemezhetô (Csathó et al. 1998, 2007). Az eltérô megközelítések ellenére, a környezetkímélő MTA TAKI - MTA MGKI rendszer ajánlásaival kapott szemtermés mennyiségek gyakorlatilag azonosaknak voltak tekinthetők az intenzív MÉM NAK rendszer ajánlásaival kapottakkal. Ez azt is jelentette, hogy a területegységre jutó nettó jövedelem a költség- és környezetkímélő MTA TAKI - MTA MGKI rendszer ajánlásainál volt a legnagyobb (Csathó et al. 2007).

A három kísérleti helyet összehasonlítva, többé-kevésbé a kísérletek harmadik éve után mért talaj $\mathrm{AL}-\mathrm{K}_{2} \mathrm{O}$ tartalmak is összefüggést mutattak a kísérletek beállításakor, 2003 ôszén mért AL-K 20 tartalmakkal, bár, az egyes helyek közötti különbségek csökkentek a harmadik év utáni abszolút és K-kontroll (NP) parcellákon mért AL- $\mathrm{K}_{2} \mathrm{O}$ tartalmakban (4. B. ábra).

A harmadik év után, a homokos vályog fizikai féleségú balatonszentgyörgyi (IMPHOS 1) kísérlet mind a hat szaktanácsadási kezelésében jó K ellátottságokat

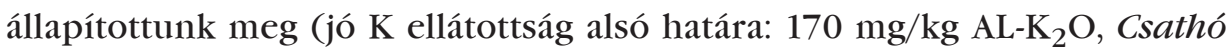
2005a). A mezőkövesdi agyagos vályog fizikai féleségú talajon (IMPHOS 2 kísérlet) (jó K ellátottság alsó határa: 190 mg/kg AL-K ${ }_{2} \mathrm{O}$, Csathó 2005a) és a nagyhörcsöki, könnyú vályog fizikai féleségú talajon (IMPHOS 3 kísérlet) (jó K ellátottság alsó határa: $180 \mathrm{mg} / \mathrm{kg}$ AL- $\mathrm{K}_{2} \mathrm{O}$, Csathó 2005a) ezekben a kezelésekben a közepes ellátottság felsô határt jelezték a harmadik év utáni AL- $\mathrm{K}_{2} \mathrm{O}$ tartalmak (4. B. ábra). A korábbi hazai szabadföldi trágyázási tartamkísérletek tanúsága szerint, sokkal nehezebb az agyagos vályog talajok AL-K tartalmat növelni, mint pl. egy homokos vályog talajét (Debreczeni és Debreczeni 1994, Debreczeni és Németh 2009).

\section{Az NPK mérleg eredmények értékelése}

Az IMPHOS kísérletekben a kísérletek harmadik éve utáni becsült kumulált NPK mérleg értékeket az NPK adagok, a termésszintek, a betakarított termés NPK tartalma, és a melléktermékek sorsa is befolyásolták. Az utóbbi eltéróen alakult a három kísérleti helyen (4. táblázat). 


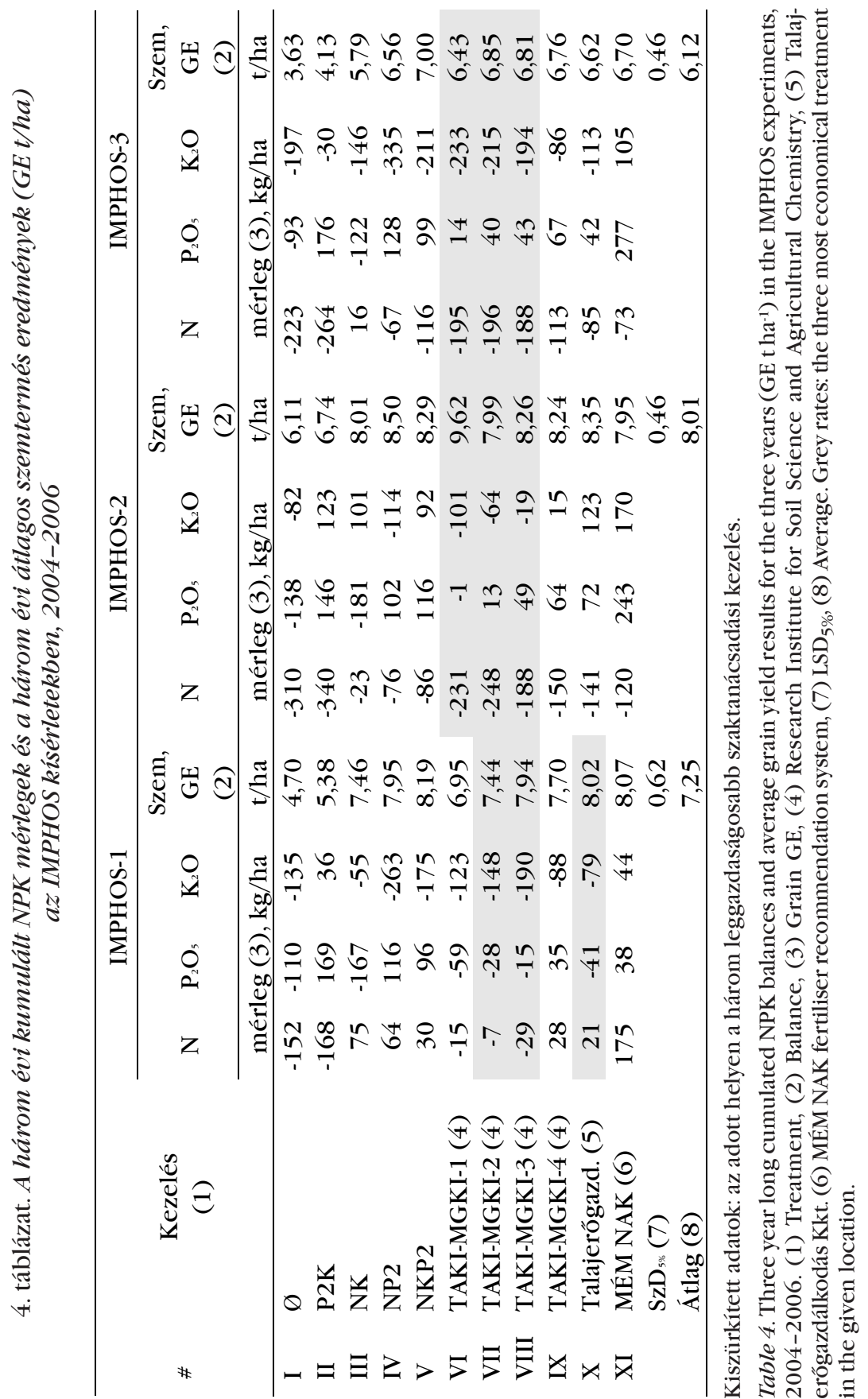


Az NPK adagokról az 1., 2. és 3. táblázatokból, a szemtermés mennyiségekről korábbi közleményünkből tájékozódhatunk (Csathó et al. 2007). A melléktermékek sorsa az alábbiak szerint alakult az egyes kísérletekben: Balatonszentgyörgy (IMPHOS 1) kísérlet: a búza és az árpa szalma lekerültek, a kukorica szár a területen maradt; Mezőkövesd (IMPHOS 2) kísérlet: a búza és az árpa szalma, valamint a kukorica szár is a területen maradtak; Nagyhörcsök (IMPHOS 3) kísérlet: a búza és az árpa szalma, valamint a kukorica szár is lekerültek a területekrôl.

A hat szaktanácsadási kezelésben a gabonaegységben (GE t/ha) kifejezett három évi átlagos szemtermés mennyiségek 7 t/ha körül alakultak a nagyhörcsöki (IMPHOS 3) kísérletben, míg 8 t/ha körül a balatonszentgyörgyi (IMPHOS 1) és a mezókövesdi (IMPHOS 2) kísérletekben. A három év átlagában, az NPK hatások hasonlóan alakultak az IMPHOS 1 és az IMPHOS 3 kísérletekben (2,8; 0,7; 0,3 t/ha, és 2,9; 1,2; 0,4 t/ha), míg sokkal kevésbé kifejezettek voltak az IMPHOS 2 kísérletben (1,6;0,3;0,0 t/ha). Ez a N és a K tekintetében jól összefüggésbe hozható a talajok eredeti N és K ellátottságával. A P hatások a vártnál valamivel nagyobbak voltak az IMPHOS 1 kísérletben, ugyanakkor a vártnál kisebbnek bizonyultak az IMPHOS 2 kísérletben. Ez utóbbi azzal is magyarázható, hogy a 2003 ószén kijuttatott 2 t/ha mészadag hatására javulhatott a P vegyületek felvehetôsége ezen az eredetileg erôsen savanyú (pH: 4,49) agyagos vályog, a foszfort erôsen fixáló talajon (4. táblázat).

A három év átlagában a hat szaktanácsadási kezelés szemtermése között nem volt szignifikáns különbség. Ez alól csupán az MTA TAKI - MTA MGKI 1. (minimum) szintje volt kivétel, a másik öt ajánlási szint három évi átlagtermése nem különbözött megbízhatóan.

A kísérletek valamennyi kezelését figyelembe véve, a N mérlegek az IMPHOS 2 kísérletben, a P mérlegek az IMPHOS 1 kísérletben, míg a K mérlegek az IMPHOS 3 kísérletben voltak a legnegatívabbak.

Az egyes kísérleteken belül, a kezeléseket összehasonlítva, magától érthetô módon, az abszolút kontrol, a N- (PK), a P- (NK), ill. a K- (NP) kontrollokon kaptunk a legnegatívabb NPK mérlegeket. A hat szaktanácsadási kezelés között, a legtöbb esetben, a költség- és környezetkímélő MTA TAKI - MTA MGKI rendszer négy ajánlási szintjén voltak a legkevésbé pozitívak az NPK mérlegek. A Talajerőgazdálkodás integrált rendszer kezelései az MTA TAKI - MTA MGKI rendszer 4. (maximum) ajánlási szintjén kapottakhoz hasonló NPK mérlegeket eredményeztek, a K kivételével az IMPHOS kísérletben, ahol jó - igen jó a 
talaj eredeti K ellátottsága, és ahol a Talajerőgazdálkodás kezelésben a K mérleg pozitívabb. A hat szaktanácsadási kezelés közül a MÉM NAK intenzív rendszer ajánlásainál kaptuk a legpozitívabb NPK mérlegeket (4. táblázat).

Tekintettel arra, hogy hasonlóan nagy terméseket kisebb NPK mérleg értékek mellett értünk el az MTA TAKI - MTA MGKI rendszer négy ajánlási szintjén, és a Talajerôgazdálkodás integrált rendszer ajánlásával, mint a MÉM NAK intenzív rendszer ajánlásával, az elốzô ajánlások alkalmazása mind agronómiai, mind környezetvédelmi, mind gazdaságossági szempontokból kedvezôbb volt. A MÉM NAK intenzív rendszer ugyanakkor történelmi küldetést töltött be, és elévülhetetlen érdemeket szerzett talajaink foszforral és káliummal való feltöltésében abban az idôszakban, amikor még alacsonyak voltak a mútrágyaárak.

A kísérletek 3. éve után a PK mérlegértékekben kimutatott különbségek jó összefüggést mutattak a talajok AL-PK tartalmában megnyilvánuló eltérésekkel (4. táblázat, 4. AB. ábra).

\section{IRODALOM}

Bergmann, W. (ed.): 1992. Nutritional disorders of plants: development, visual and analytic diagnosis. Gustav Fischer. Jena. Stuttgart. New York.

Buzás I.: 1988. Talaj- és agrokémiai vizsgálati módszerkönyv. II. A talajok fizikai-kémiai és kémiai tulajdonságainak vizsgálati módszerei. Mezógazdasági Kiadó. Budapest. 243

Csathó P.: 2002. Az AL-P korrekciós modell értékelése a hazai szabadföldi ôszi búza P kísérletek adatbázisán, 1960-2000. Agrokémia és Talajtan. 51: 351-380.

Csathó P.: 2003a. Őszi búza N-hatásokat befolyásoló tényező́k vizsgálata az 1960 és 2000 között publikált hazai szabadföldi kísérletek adatbázisán. Növénytermelés. 52. 1: 41-59.

Csathó P.: 2003b. Lucerna N hatásokat befolyásoló tényezők vizsgálata az 1960 és 2000 között publikált hazai szabadföldi kísérletek adatbázisán. Növénytermelés. 52. 3: $243-253$.

Csathó P.: 2003c. Kukorica N hatásokat befolyásoló tényezók vizsgálata az 1960 és 2000 között publikált hazai szabadföldi kísérletek adatbázisán. Agrokémia és Talaj$\tan$. 52: 169-184.

Csathó P.: 2003d. Kukorica P hatásokat befolyásoló tényező́k vizsgálata az 1960 és 2000 között publikált hazai szabadföldi kísérletek adatbázisán. Szemle. Agrokémia és Talajtan. 52. 455-472. 
Csathó P.: 2003e. Ôszi búza P-hatásokat befolyásoló tényezók vizsgálata az 1960 és 2000 között publikált hazai szabadföldi kísérletek adatbázisán. Növénytermelés. 52. 6: 679-701.

Csathó P.: 2004a. Lucerna P-hatásokat befolyásoló tényezók vizsgálata az 1960 és 2000 között publikált hazai szabadföldi kísérletek adatbázisán. Növénytermelés. 53. 2: $141-156$.

Csathó P.: 2004b. A talaj-növény rendszer tápelemforgalmának agronómiai és környezetvédelmi vonatkozásai. MTA Doktori Értekezés Tézise. MTA, Budapest - MTA TAKI. Budapest. Kézirat. 24.

Csathó P.: 2005a. Ôszi búza K hatásokat befolyásoló tényezők vizsgálata az 1960 és 2000 között publikált hazai szabadföldi kísérletek adatbázisán. Szemle. Növénytermelés. 54. 2: 197-213.

Csathó P.: 2005b. Kukorica K hatásokat befolyásoló tényezók vizsgálata az 1960 és 2000 között publikált hazai szabadföldi kísérletek adatbázisán. Szemle. Növénytermelés. 54. 4: 447-465.

Csathó, P.-Árendás, T.,-Németh, T.: 1998. New, environmentally friendly fertiliser advisory system, based on the data set of the Hungarian long-term field trials set up between 1960 and 1995. Communications in Soil Science and Plant Analysis. 29: 2161-2174.

Csathó P.-Árendás T.-Fodor N.-Németh T.: 2007. A legelterjedtebb hazai trágyázási szaktanácsadási rendszerek tesztelése szabadföldi kísérletekben. Szemle. Agrokémia és Talajtan. 56: 173-190.

Csathó, P.-Árendás, T.-Fodor, N.-Németh, T.: 2009. Evaluation of different fertilizer recommendation systems on various soils and crops in Hungary. Communications in Soil Science and Plant Analysis. 40: 1689-1711.

Debreczeni B.-Debreczeni K. (szerk.): 1994. Trágyázási Kutatások 1960-1990. Akadémiai Kiadó. Budapest. 411.

Debreczeni B.-né-Németh T. (szerk.): 2009. Az Országos Mútrágyázási Tartamkísérletek (OMTK) kutatási eredményei (1967-2001). Akadémiai Kiadó. Budapest. 296-319.

Egner, H.-Riehm, H.-Domingo, W. R.: 1960. Untersuchungen über die chemische Bodenanalyse als Grundlage für die Beurteilung des Nährstoffzustandes der Böden. II. Chemische Extraktionsmethoden Zur Phosphor-und Kalium Bestimmung. Kungl. Lantbrukshögskolans Annaler (Annals of the Royal Agricultural College. Sweden) 26: 199-215.

Győrffy B.: 1979. A kukoricaszár trágyahatásának vizsgálata tartamkísérletben, 19581974. [In: Bajai J. (szerk.) Kukoricatermesztési kísérletek 1968-1974.] Akadémiai Kiadó. Budapest. 243-249.

Holló S.-Csathó P.-Sarkadi J.: 1991. A foszfor mútrágyázás hatékonysága kukorica-tavaszi árpa-ôszi búza vetésváltásban egy csernozjom barna erdőtalajon. Növénytermelés. 40. 1: 51-66. 
Izsáki, Z.: 2006. Relationship between potassium supplies of the soil and nutrient concentration of maize (Zea mays L.) leaves. Cereal Res. Commun. 34: 501-504.

Izsáki Z.: 2007. Összefüggés a talaj N, P, és K ellátottsága és a kukorica (Zea mays L.) terméshozama közötti. Acta Agronomica Óváriensis. 49: 207-212.

Izsáki, Z.: 2008. Effect of soil P supply on P-Zn interactions in a maize (Zea mays L.) long-term field experiment. Cereal Res. Commun. 36: 1851-1854.

Izsáki, Z.: 2009. Effect of nitrogen supply on nutritional status of maize. Communications in Soil Science and Plant Analysis. 40: 960-973.

Izsáki, Z.-Németh, K. T.: 2007. Use of chlorophyll meter to determine the nitrogen status of winter barley. Cereal Res. Commun. 35: 521-524.

Jones, J. B.: 1967. Interpretation of plant analysis for several agronomic crops. [In: Hardy, G. W. (ed.) Soil Testing and Plant Analysis: part 2.] SSSA Spec. Publ. SSSA Inc. Madison. WI. 2: 49-85.

Jones, J. B. Jr.-Wolf, B. -Mills, H. A.: 1991. Plant analysis handbook; A practical sampling, preparation, analysis, and interpretation guide. Micro-Macro Inc., Athens. USA.

Kádár I.: 1992. A növénytáplálás alapelvei és módszerei. MTA TAKI -AKAPRINT. Budapest. 398.

Kádár, I.: 1994. Importance of long-term field experiments in sustainable agriculture. Agrokémia és Talajtan. 43: 291-304.

Kadlicskó B.-Krisztián J.: 1977. N-P-K mútrágya adagolási kísérletek kukoricával és tavaszi árpával, erodált agyagbemosódásos barna erdôtalajon. Növénytermelés. 26. 3: 315-322.

Khasawneh, F. E.-Sample, E. C.-Kamprath, E.J. (eds.): 1980. The role of phosphorus in agriculture. ASA, CSSA, SSSA, Madison. Wisconsin. USA.

Kismányoky T.-Balázs J.-Hoffmann S.-Kováts A.-Szanyi M.: 1989. Gabonás vetésforgó N-forgalmának vizsgálata. [In: MAE Talajtani Társaság Vándorgyúlése. Szarvas, 1988. 09. 1-2.] Agrokémia és Talajtan. 38: 93-97.

Lásztity B.: 1991. A feltöltô adagú foszfor- és kálium mútrágyázás utóhatásainak vizsgálata karbonátos gyengén humuszos homoktalajon. Agrokémia és Talajtan. 40: 419-430.

MÉM NAK: 1979. Fertilization directives on farm-level. [Buzás, I.-Fekete, A. (eds.)] Mezőgazdasági Kiadó. Budapest.

Munson, R. D. (ed.): 1985. Potassium in agriculture. ASA, CSSA, SSSA. Madison. Wisc. USA.

Németh, T.: 2006. Application of the Bray-Mitscherlich equation approach for economically and environmentally sound fertilization of field crops in Hungary. Commun. in Soil Sci. and Plant Anal. 37: 2227-2247.

Olson, R. A.-Frank, K. D.-Grabouski, P. H.-Rehm, G. W.: 1982. Economic and agronomic impacts of varied philosophies of soil testing. Agronomy Journal. 74: 492-499.

Peverill, K. I.-Sparrow, L. A.-Reuter, D. J. (eds.): 1999. Soil Analysis. An Interpretation Manual. CSIRO Publishing. Collingwood. Australia. 369. 
Reuter, D. J.-Robinson, J. B.-Dutkiewicz, C. (eds.): 1997. Plant Analysis. An Interpretation Manual. Second Edition. CSIRO Publishing. Collingwood. Australia. 572.

Sulyok D.-Csathó P.-Árendás T.-Fodor N.-Németh T.: 2007a. Az ôszi búza (Triticum aestivum L.) termesztésének ökonómiai elemzése mútrágyázási kísérletben. Agrárunió. 8. 2: 27-29.

Sulyok D. -Csathó P.-Árendás T.-Fodor N.-Németh T.: 2007b. A kukorica (Zea mays L.) termesztésének ökonómiai elemzése mútrágyázási kísérletben. Agrárunió. 8. 3: 22-26.

Tyurin, I. V.: 1937. Organicheskoe veschestvo pochvi (A talajok szervesanyag tartalma). Selhozgiz. Moscow.

www.talajerogazdalkodas.hu

A szerzôk levelezési címe - Address of the autors:

Dr. Árendás Tamás

MTA Mezógazdasági Kutatóintézet

Martonvásár

Brunszkiv u. 2.

H-2462

Dr. Fodor Nándor-Dr. Csathó Péter-Dr. Radimszky László

MTA Talajtani és Agrokémiai Kutatóintézet

Budapest

Herman Ottó u. 15.

H-1022

Dr. Horváth József

Talajerôgazdálkodás Kkt

Kaposvár

Petôfi S. u. 11.

H-7400

Dr. Németh Tamás

Magyar Tudományos Akadémia

Budapest

Roosevelt tér 9.

H-1051 